\title{
Mariniflexile fucanivorans sp. nov., a marine member of the Flavobacteriaceae that degrades sulphated fucans from brown algae
}

Correspondence

Tristan Barbeyron barboun@sb-roscoff.fr

\author{
Tristan Barbeyron, ${ }^{1}$ Stéphane L'Haridon, ${ }^{2}$ Gurvan Michel ${ }^{1}$ \\ and Mirjam Czjzek ${ }^{1}$
}
${ }^{1}$ Centre National de la Recherche Scientifique, Université Pierre et Marie Curie-Paris 6, Unité Mixte de Recherche 7139 'Végétaux Marins et Biomolécules', Station Biologique, F-29682 Roscoff Cedex, Bretagne, France
${ }^{2}$ Centre National de la Recherche Scientifique, Université de Bretagne Occidentale, IFREMER, Unité Mixte de Recherche 6197 'Laboratoire de Microbiologie des Environnements Extrêmes', IFREMER, F-29280 Plouzané, Bretagne, France

Sulphated fucans are matrix polysaccharides from the cell wall of marine fucalean brown algae, consisting of an $\alpha$-Lfucose backbone substituted by sulphate ester groups and branched with other monosaccharide residues (Mabeau \& Kloareg, 1987; Kloareg \& Quatrano, 1988; Mabeau et al., 1990). In fucalean brown algae such as Pelvetia canaliculata, Ascophyllum nodosum and Fucus spiralis, the repetitive unit of sulphated fucans is a disaccharide consisting of $\alpha$ 1,3-L-fucopyranose 2 -sulphate- $\alpha$-1,4-L-fucopyranose 2,3 disulphate, with the 3 -linked residue at the non-reducing end (Descamps et al., 2006). A recently isolated bacterial strain, SW5 $5^{\mathrm{T}}$, produced an extracellular enzyme that specifically hydrolysed the $\alpha-1,4$ linkage of sulphated fucans from fucalean brown algae (Descamps et al., 2006). The gene encoding this fucanase has been cloned (Colin et al., 2006) and the enzyme was shown to belong to family 107 of glycoside hydrolases (http://www.cazy.org).

The GenBank/EMBL/DDBJ accession number for the $16 \mathrm{~S}$ rRNA gene sequence of strain $\mathrm{SW}^{\top}$ is AJ628046.

A photograph of colonies of strain $S W 5^{\top}$ on ZoBell agar and a phasecontrast micrograph of a ZoBell broth culture are available as supplementary material with the online version of this paper.
In this study, we report the polyphasic characterization of strain $S W 5^{\mathrm{T}}$ as a representative of a novel species of the genus Mariniflexile. The genus Mariniflexile, a member of the family Flavobacteriaceae (Bernardet et al., 1996, 2002; Bernardet \& Nakagawa, 2006) of the phylum Bacteroidetes, initially contained only Mariniflexile gromovii, isolated from the sea urchin Strongylocentrotus intermedius (Nedashkovskaya et al., 2006).

Strain $\mathrm{SW} 5^{\mathrm{T}}$ was isolated from mud of a water-treatment facility (Descamps et al., 2006) at Landerneau (Brittany, France) that recycled the effluent of an alginate-extraction plant. For direct comparison, M. gromovii KMM $6038^{\mathrm{T}}$ was studied in parallel with strain SW5 ${ }^{\mathrm{T}}$ in all phenotypic tests (except for growth at different temperatures, $\mathrm{pH}$ and $\mathrm{NaCl}$ concentrations) and whole-cell protein analysis. The two strains were routinely cultivated in ZoBell medium 2216E (ZoBell, 1941), solidified when necessary with $1.5 \%(\mathrm{w} / \mathrm{v})$ agar. Pure cultures were stored at $-80{ }^{\circ} \mathrm{C}$ in culture medium containing $20 \%$ (v/v) glycerol. Growth was monitored by the increase of optical density at $600 \mathrm{~nm}$, using a UV1601 spectrophotometer (Shimadzu). All growth experiments were performed in triplicate. The temperature range for growth was evaluated at $4,10,15$, 
20, 25, 32 and $37{ }^{\circ} \mathrm{C}$. The optimal $\mathrm{pH}$ was determined at $25{ }^{\circ} \mathrm{C}$ in Cytophaga marine broth (DSMZ medium 172) with the $\mathrm{pH}$ adjusted using $10 \mathrm{mM}$ MES for $\mathrm{pH} 5.0,5.5$ and 6.0, $10 \mathrm{mM}$ PIPES for $\mathrm{pH} 6.5$ and 7.0, $10 \mathrm{mM}$ HEPES for $\mathrm{pH} 7.5,10 \mathrm{mM}$ Tris for $\mathrm{pH} 8.0$ and 8.5 and no buffer for $\mathrm{pH}$ 9.0. The effect of $\mathrm{NaCl}$ on growth was determined at $25{ }^{\circ} \mathrm{C}$ in the same medium containing $0-9 \%(\mathrm{w} / \mathrm{v}) \mathrm{NaCl}$ at $1 \%$ intervals.

Genomic DNA was extracted by using the procedure described by Barbeyron et al. (1984) and purified on a caesium chloride gradient. The Chargaff s coefficient of the genomic DNA, expressed as the molar percentage of $\mathrm{G}+\mathrm{C}$, was determined by the DSMZ using the HPLC method. Genomic DNA extracted from strain $S W 5^{\mathrm{T}}$ displayed a Chargaff's coefficient (DNA G + C content) of $34.5 \mathrm{~mol} \%$. The 16S rRNA gene sequence from strain $S W 5^{\mathrm{T}}$ was amplified by PCR using purified genomic DNA as template and the bacterial domain-specific primers 8F (Hicks et al., 1992) and 1492R (Kane et al., 1993). PCRs were typically carried out in a volume of $50 \mu \mathrm{l}$ containing $10-100 \mathrm{ng}$ template, $0.4 \mu \mathrm{M}$ of each specific primer, $250 \mu \mathrm{M}$ each dNTP, $0.1 \mathrm{mg}$ BSA, $1 \times$ GoTaq buffer (Promega) and 1.25 U GoTaq DNA Polymerase (Promega). The thermal profile of the PCR was 2 min at $95{ }^{\circ} \mathrm{C}$ followed by 30 cycles of $0.5 \mathrm{~min}$ at $95{ }^{\circ} \mathrm{C}, 0.5 \mathrm{~min}$ at $50{ }^{\circ} \mathrm{C}$ and $1.5 \mathrm{~min}$ at $72{ }^{\circ} \mathrm{C}$ and a final polymerization step of $4 \mathrm{~min}$ at $72{ }^{\circ} \mathrm{C}$. PCR products were purified with the MinElute PCR purification kit (Qiagen), cloned in vector pCRII2.1 and sequenced using Big Dye-labelled dideoxyribonucleotides, the Thermosequenase kit (Amersham) and an ABI Prism 3130xl Genetic Analyzer (Applied Biosystems/Hitachi). The 16S rRNA gene sequence of strain $S W 5^{\mathrm{T}}$ was aligned using the MAFFT software (Katoh et al., 2002, 2005) with a representative set of sequences obtained from GenBank (Benson et al., 1999) and the alignment was then refined manually. The secondary structure was used as a guide to ensure that only homologous regions were compared. Of the 1474 nucleotides that were sequenced, 1286 were used in the phylogenetic analysis. The neighbour-joining algorithm (Saitou \& Nei, 1987) was used with Kimura's distance correction (Kimura, 1980) and bootstrap analysis was performed to provide confidence estimates for the phylogenetic tree topologies (Felsenstein, 1985). The maximum-parsimony (Fitch, 1971) and maximum-likelihood (Felsenstein, 1981) methods were also applied, as implemented in the PHYLO_WIN package (Galtier et al., 1996). Although some differences were observed between trees generated by the neighbour-joining, maximumlikelihood and maximum-parsimony methods, all phylogenetic trees based on 16S rRNA gene sequences showed that $\mathrm{SW} 5^{\mathrm{T}}$ branched with M. gromovii KMM $6038^{\mathrm{T}}$ (Fig. 1) with a bootstrap value of $100 \%$. Pairwise comparisons of $16 \mathrm{~S}$ rRNA gene sequences were made using the FASTA software (Pearson \& Lipman, 1988). The 16S rRNA gene sequence of strain SW5 $5^{\mathrm{T}}$ shared 98.4, 94.5, 94.1 and $94 \%$ similarity, respectively, with those of $M$. gromovii KMM $6038^{\mathrm{T}}$ (Nedashkovskaya et al., 2006), Gaetbulibacter saemankumensis SMK-12 $2^{\mathrm{T}}$ (Jung et al., 2005), Yeosuana aromativorans GW1-1 ${ }^{\mathrm{T}}$ (Kwon et al., 2006) and Algibacter lectus KMM $3902^{\mathrm{T}}$ (Nedashkovskaya et al., 2004). Sequence similarity with Winogradskiella species (Nedashkovskaya et al., 2005), Tamlana crocina HST1-43 ${ }^{\mathrm{T}}$ (Lee, 2007) and Olleya marilimosa $\mathrm{CAM} 030^{\mathrm{T}}$ (Nichols et al., 2005) was $93 \%$ and similarity to other species used in the phylogenetic analysis was $<93 \%$. DNA relatedness between strain $\mathrm{SW}^{\mathrm{T}}$ and M. gromovii $\mathrm{KMM} 6038^{\mathrm{T}}$ was

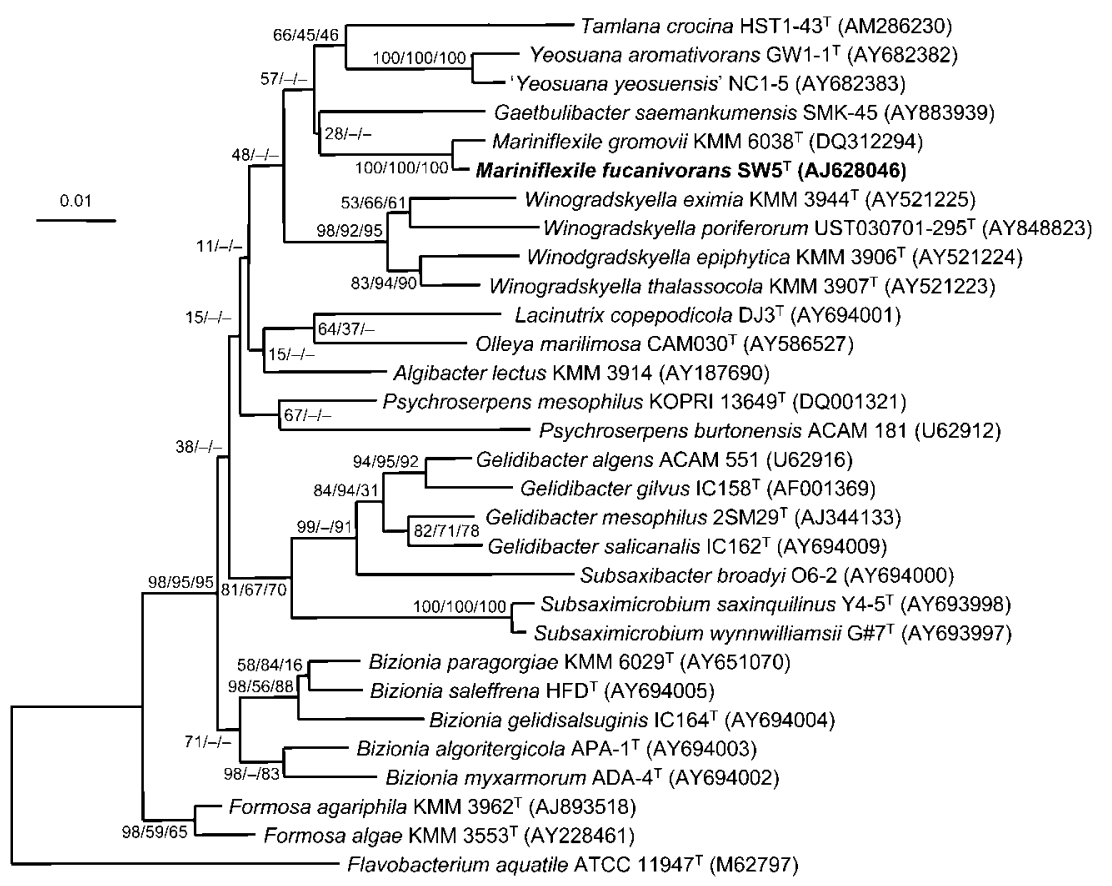

Fig. 1. Neighbour-joining tree showing the phylogenetic position of strain $\mathrm{SW}^{\mathrm{T}}, \mathrm{M}$. gromovii $\mathrm{KMM} 6038^{\top}$ and representatives of other genera of the family Flavobacteriaceae. GenBank accession numbers are given in parentheses. Numbers at branching points are bootstrap percentages (from 500 replicates) in distance, maximum-likelihood and maximum-parsimony analyses, respectively; dashes indicate that the node was not observed in the corresponding analysis. Flavobacterium aquatile ATCC $11947^{\top}$ was used as an outgroup. Bar, 0.01 substitutions per nucleotide position. 
investigated by slot-blot DNA-DNA hybridization, using the ECF random-prime labelling and signal amplification system (Amersham Life Sciences), following the procedure described by Kristjánsson et al. (1994). Amounts of 25, 50, 75 and 100 ng target DNA denatured in $0.4 \mathrm{M} \mathrm{NaOH}$ were slotted onto a nylon hybridization membrane (Bio-Rad) and probed with $200 \mathrm{ng}$ fluorescein-labelled tracer DNA. For each triplicate of DNA-DNA association, the hybridization temperature was chosen in the optimal range of the hybridization buffer (Johnson, 1984; Ivanova et al., 1988). Final high-stringency washes and signal amplification were performed according to the manufacturer's instructions (Amersham Life Sciences). Hybridization signals were detected with a Typhoon 640 fluorescence scanner (Molecular Dynamics) and analysed with the IMAGEQUANT program. The signal (maximum peak area) produced by hybridization of the probe with homologous target DNA was set as $100 \%$ and compared with the signal generated by heterologous DNA. When the DNA from $\mathrm{SW}^{\mathrm{T}}$ was used to probe the DNA of M. gromovii KMM $6038^{\mathrm{T}}$ or vice versa, the level of DNA-DNA reassociation was $\leqslant 25 \%$. This value is well below that observed at the species level (Stackebrandt \& Goebel, 1994), suggesting that SW $5^{\mathrm{T}}$ represents a novel species of the genus Mariniflexile.

Similar to M. gromovii KMM $6038^{\mathrm{T}}$, strain $\mathrm{SW} 5^{\mathrm{T}}$ formed circular, shiny, dark-yellow colonies, $2 \mathrm{~mm}$ in diameter, on ZoBell agar within 5 days at $20{ }^{\circ} \mathrm{C}$. No spreading occurred at the margins of colonies of either strain (see Supplementary Fig. S1 available in IJSEM Online). Cell morphology and gliding motility were investigated on wet mounts of an exponential ZoBell broth culture at $20{ }^{\circ} \mathrm{C}$ by phase-contrast microscopy (Olympus $\mathrm{BH} 2$ microscope; $\times 1000$ ). Cells of strain $S W 5^{\mathrm{T}}$ were round-ended rods, about $0.3-0.5 \mu \mathrm{m}$ in diameter and $3.5-4.0 \mu \mathrm{m}$ long, occurring singly or in pairs (Supplementary Fig. S2). Under the same growth conditions, M. gromovii KMM $6038^{\mathrm{T}}$ formed shorter cells $(\sim 2.0 \mu \mathrm{m})$. Stationary-phase cultures of strain $\mathrm{SW5}^{\mathrm{T}}$ also contained shorter cells $(\sim 1.0 \mu \mathrm{m})$ and non-refractive spherical bodies. Cells were non-flagellated, adhered to the slide and to the coverslip, displayed active gliding motility and stained Gram-negative using the method described by Doetsch (1981).

To determine the type of respiratory metabolism, strain SW $5^{\mathrm{T}}$ was inoculated in Veillon's tubes containing ZoBell medium solidified with $0.6 \%(\mathrm{w} / \mathrm{v})$ agar. Oxygen was removed from the medium by boiling. To determine whether metabolism was oxidative or fermentative, strain $\mathrm{SW}^{\mathrm{T}}$ was inoculated in a modified Leifson O-F medium (Hugh \& Leifson, 1953; Smibert \& Krieg, 1981) containing $0.5 \%(\mathrm{w} / \mathrm{v})$ glucose. Cytochrome oxidase activity was assayed by vigorous shaking of cells from a $2.5 \mathrm{ml}$ broth culture for $5 \mathrm{~min}$ in $0.5 \mathrm{ml}$ natural seawater in the presence of $20 \mu \mathrm{l}$ dimethylparaphenylene diamine oxalate (bioMérieux). The presence of the enzyme was revealed by a blue coloration of the cellular suspension. Catalase activity was assayed by mixing a colony from a ZoBell agar plate with a drop of $10 \%(\mathrm{v} / \mathrm{v})$ hydrogen peroxide.
Amylase activity was assayed on $0.2 \%$ (w/v) soluble starch ZoBell agar plates. DNase activity was detected in DNA agar (Difco), prepared with seawater. Amylase and DNase activities were revealed by flooding the plates with Lugol solution or $1 \mathrm{M} \mathrm{HCl}$, respectively. Agarase, $\kappa$-carrageenase and $l$-carrageenase activities were tested by inoculating ZoBell medium solidified with $15 \mathrm{~g}$ agar, $10 \mathrm{~g} \kappa$-carrageenan or $20 \mathrm{~g} l$-carrageenan $\mathrm{l}^{-1}$, respectively. Strains were considered positive when colonies were located in craters in the substrate. Intracellular and extracellular fucanase activities of strain SW5 ${ }^{\mathrm{T}}$ and M. gromovii $\mathrm{KMM} 6038^{\mathrm{T}}$ were assayed by incubating sulphated fucans with protein extracts from bacterial cells cultivated in ZoBell broth supplemented by $0.2 \%(\mathrm{w} / \mathrm{v})$ sulphated fucans (intracellular activity) and with a cell-free supernatant from the same medium (extracellular activity). The degradation products were revealed by carbohydrate-PAGE (C-PAGE; Zablackis \& Perez, 1990). The presence of oligofucans in the polyacrylamide gels revealed the presence of a fucanase activity. Extraction of sulphated fucan from the brown alga Pelvetia canaliculata and C-PAGE staining were performed as described previously (Descamps et al., 2006). Production of flexirubin-type pigments was assessed by flooding a 4 day plate culture with $20 \%(\mathrm{w} / \mathrm{v}) \mathrm{KOH}$, followed by the observation of changes in colony colour from yellow to red or brown (Reichenbach et al., 1974).

Strain SW5 ${ }^{\mathrm{T}}$ was strictly aerobic, chemo-organotrophic and heterotrophic, with an oxidative metabolism that used oxygen as the electron acceptor. Nitrate could not be used as an electron acceptor. Strain $\mathrm{SW}^{\mathrm{T}}$ and $M$. gromovii KMM $6038^{\mathrm{T}}$ were cytochrome oxidase-negative and catalase-positive and did not synthesize flexirubin. Unlike M. gromovii $\mathrm{KMM} 6038^{\mathrm{T}}$, strain $\mathrm{SW}^{\mathrm{T}}$ hydrolysed the sulphated fucoidan from Pelvetia canaliculata (Fig. 2). The ability to use simple carbohydrates as carbon sources was tested in artificial seawater supplemented with $2 \mathrm{~g}$ ammonium nitrate, $250 \mathrm{mg}$ Casamino acids and $150 \mathrm{mg}$ yeast extract $1^{-1}$ and containing the carbohydrate under investigation at a concentration of $0.5 \%(\mathrm{w} / \mathrm{v})$. Other tests were performed by using the identification strips API 20 NE, API ZYM and API 50CH (bioMérieux). The latter were used in both the acidification (with the API 50CHB/E medium) and assimilation modes using a medium containing $2 \mathrm{~g}$ ammonium sulphate, $100 \mathrm{mg}$ yeast extract and $1.5 \mathrm{~g}_{\text {agar }} \mathrm{l}^{-1}$ in $40 \mathrm{mM}$ phosphate buffer, $\mathrm{pH}$ 8. All culture media were supplemented to $25 \mathrm{~g} \mathrm{NaCl} \mathrm{l}^{-1}$. Biolog GN2 microplates were inoculated with bacterial suspensions in a medium that contained $25 \mathrm{~g} \mathrm{NaCl}, 8 \mathrm{~g} \mathrm{MgCl} 2$ and $0.5 \mathrm{~g} \mathrm{KCl} \mathrm{l}^{-1}$. API galleries and GN2 microplates were incubated at $20{ }^{\circ} \mathrm{C}$ for 2 weeks. Sensitivity to $\left(\mu \mathrm{g} \mathrm{ml}{ }^{-1}\right)$ chloramphenicol (10), penicillin G (200), streptomycin (200), kanamycin (200), ampicillin (200), rifampicin (10) and tetracycline (10) (all from Sigma-Aldrich) was tested at $20{ }^{\circ} \mathrm{C}$ in Cytophaga marine broth. The phenotypic characteristics of strain $\mathrm{SW} 5^{\mathrm{T}}$ are compared with those of M. gromovii $\mathrm{KMM} 6038^{\mathrm{T}}$ in Table 1. Overall, the results obtained in this study for the latter strain are in agreement 


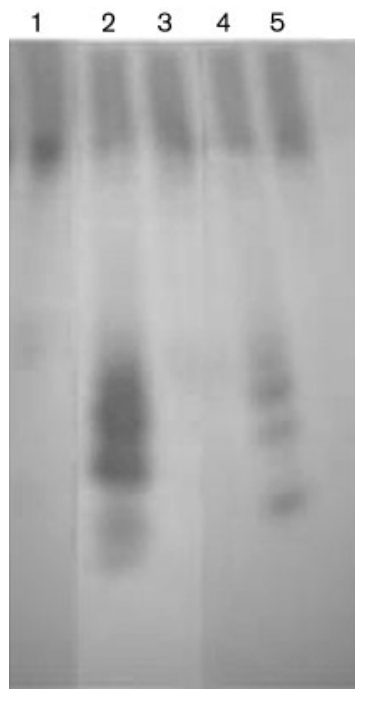

Fig. 2. C-PAGE of oligofucans generated by cell extracts (lanes 2 and 3) and culture supernatants (lanes 4 and 5) from strain SW5 ${ }^{\top}$ (lanes 2 and 4) and M. gromovii KMM 6038 ${ }^{\top}$ (lanes 3 and 5). The substrate fucan from Pelvetia canaliculata is shown as a control (lane 1).

with previously published data (Nedashkovskaya et al., 2006) except that we could not confirm the presence of cytochrome oxidase activity.

Cellular proteins were extracted from the cell pellet of $2.0 \mathrm{ml}$ of a $48 \mathrm{~h} \mathrm{ZoBell} \mathrm{broth} \mathrm{culture} \mathrm{at} 20^{\circ} \mathrm{C}$ washed twice with artificial seawater. Cells were disrupted by vigorous shaking in $375 \mu \mathrm{l}$ BugBuster protein extraction reagent (Novagen) and left on ice for $10 \mathrm{~min}$. The proteins were denatured for $5 \mathrm{~min}$ at $100{ }^{\circ} \mathrm{C}$ in $125 \mu \mathrm{l} 4 \times$ loading buffer $(60 \mathrm{mM}$ Tris/HCl, pH 6.8, $2 \%$ SDS, $0.005 \% \quad(\mathrm{w} / \mathrm{v})$ bromophenol blue, $1.4 \mathrm{M} \beta$-mercaptoethanol). Amounts of protein loaded on the SDS-PAGE gel $(20 \times 20 \mathrm{~cm}$, $1.5 \mathrm{~mm}$ thick; $12 \%(\mathrm{w} / \mathrm{v})$ polyacrylamide in running gel; $4 \%(\mathrm{w} / \mathrm{v})$ in stacking gel) were standardized with respect to the strain that had the lowest optical density. The wholecell protein profiles of strain $S W 5^{\mathrm{T}}$ and M. gromovii KMM $6038^{\mathrm{T}}$ showed significant differences (Fig. 3 ). The fatty acid composition of strain $S W 5^{\mathrm{T}}$ was determined by the DSMZ, according to the standard protocol of the MIDI Microbial Identification System (Sasser, 1990), with cells grown on TSBA40 (30 g trypticase soy broth and $15 \mathrm{~g}_{\text {agar } \mathrm{l}^{-1}}$ ) at $28^{\circ} \mathrm{C}$ for $48 \mathrm{~h}$. The fatty acid profile of strain $\mathrm{SW} 5^{\mathrm{T}}$ contained five major fatty acids: iso- $\mathrm{C}_{15: 0}(15.3 \%)$, iso$\mathrm{C}_{16: 0} 3-\mathrm{OH}(10 \%), \mathrm{C}_{15: 1}(8.7 \%)$, iso- $\mathrm{C}_{17: 0} 3-\mathrm{OH}(6.8 \%)$ and anteiso- $\mathrm{C}_{15: 0}(6.7 \%)$. The detailed fatty acid compositions of strain SW5 ${ }^{\mathrm{T}}$ and M. gromovii KMM $6038^{\mathrm{T}}$ are given in Table 2. While both strains contained similar amounts of iso- $\mathrm{C}_{17: 0} 3-\mathrm{OH}$ and iso- $\mathrm{C}_{15: 0}$, the proportions of some other compounds differed significantly, probably as a result of the use of different growth media (marine agar 2216 was used for M. gromovii $\mathrm{KMM} 6038^{\mathrm{T}}$; Nedashkovskaya et al., 2006) (Table 2).
Table 1. Phenotypic characteristics of strain $S W 5^{\top}$ and $M$. gromovii $\mathrm{KMM} 6038^{\top}$

Both strains were Gram-negative, non-flagellated rods, positive for the following characteristics: respiratory metabolism; gliding motility; presence of catalase, $\beta$-galactosidase, esterase (C4), esterase lipase (C8), alkaline and acid phosphatases, leucine, valine and cystine arylamidases, trypsin and $\alpha$-chymotrypsin activities; hydrolysis of aesculin and alginic acid; utilization of D-glucose, D-fructose, Lfucose, D-lactose, D-mannose and glucuronic acid; acid production from D-glucose, D-galactose, D-fructose, D-mannose, D-xylose, Lfucose, D-lactose and mannitol (weakly). Both strains were negative for the following characteristics: presence of cytochrome oxidase, $\alpha$ galactosidase, $\alpha$-mannosidase and $\beta$-glucuronidase activities; hydrolysis of agar and $\kappa$-carrageenan; production of flexirubin pigments; nitrate reduction; utilization of Tweens 40 and 80, L-arabinose, trehalose, glycerol, adonitol, D-arabitol, L-erythritol, inositol, Dsorbitol, $\mathrm{N}$-acetyl-D-glucosamine and $\mathrm{N}$-acetyl-D-galactosamine; production of acid from melibiose, melezitose, turanose, D-lyxose, Dtagatose, D-fucose, L-xylose, L-sorbose, glycerol, erythritol, D-adonitol, dulcitol, inositol, D-sorbitol, D- and L-arabitol, methyl $\alpha$-D-glucoside, methyl $\alpha$-D-mannoside, methyl $\beta$-D-xyloside, $N$-acetylglucosamine and inulin. Both strains were susceptible to $\left(\mu \mathrm{g} \mathrm{ml}^{-1}\right)$ ampicillin (200), tetracycline (10) and chloramphenicol (10) but not to streptomycin (200) or kanamycin (200). +, Positive; -, negative; $\mathrm{w}$, weakly positive.

\begin{tabular}{|c|c|c|}
\hline Characteristic & Strain $\mathrm{SW} 5^{\mathrm{T}}$ & $\begin{array}{l}\text { M. gromovii } \\
\text { KMM } 6038^{\mathrm{T}}\end{array}$ \\
\hline Cell length $(\mu \mathrm{m})$ & 3.5 & 2.0 \\
\hline \multicolumn{3}{|l|}{ Growth at/with: } \\
\hline $6 \%(\mathrm{w} / \mathrm{v}) \mathrm{NaCl}$ & - & $t^{*}$ \\
\hline $37^{\circ} \mathrm{C}$ & - & $t^{*}$ \\
\hline \multicolumn{3}{|l|}{ Presence of: } \\
\hline Lipase (C14) & $\mathrm{W}$ & - \\
\hline $\begin{array}{l}\alpha \text {-Glucosidase, } \beta \text {-glucosidase, } \\
\alpha \text {-fucosidase }\end{array}$ & + & - \\
\hline \multicolumn{3}{|l|}{ Hydrolysis of: } \\
\hline $\begin{array}{l}\text { l-Carrageenan, dextrin, glycogen, } \\
\text { starch }\end{array}$ & + & - \\
\hline Fucoidan from Pelvetia canaliculata & + & - \\
\hline Gelatin & - & + \\
\hline DNA & + & $\mathrm{W}$ \\
\hline \multicolumn{3}{|l|}{ Utilization of: } \\
\hline $\begin{array}{l}\text { D-Galactose, maltose, cellobiose, } \\
\text { gentiobiose }\end{array}$ & + & - \\
\hline $\begin{array}{l}\text { L-Rhamnose, sucrose, raffinose, } \\
\text { D-mannitol }\end{array}$ & - & + \\
\hline \multicolumn{3}{|l|}{ Acid production from: } \\
\hline $\begin{array}{l}\text { D-Arabinose, L-arabinose, } \\
\text { L-rhamnose, sucrose, raffinose }\end{array}$ & - & + \\
\hline $\begin{array}{l}\text { D-Ribose, cellobiose, maltose, } \\
\text { gentiobiose, amygdalin, starch, } \\
\text { glycogen, arbutin, salicin }\end{array}$ & + & - \\
\hline Trehalose, xylitol & $\mathrm{W}$ & - \\
\hline DNA G $+C$ content $(\mathrm{mol} \%)$ & 34.5 & 35.7 \\
\hline
\end{tabular}

${ }^{\star}$ Data from Nedashkovskaya et al. (2006). 


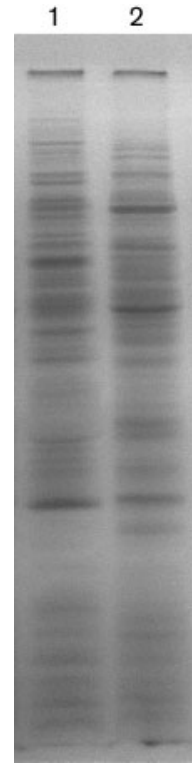

Fig. 3. SDS-PAGE of protein extracts from strain $\mathrm{SW}^{\top}$ (lane 1) and M. gromovii $\mathrm{KMM} 6038^{\top}$ (lane 2). Protein bands were visualized by staining with Coomassie blue.

The phylogenetic and fatty acid data showed that strain SW5 ${ }^{\mathrm{T}}$ belongs to the genus Mariniflexile. Phenotypic characteristics, DNA-DNA relatedness values and protein profiles support the description of strain $\operatorname{SW5}^{\mathrm{T}}$ as a representative of a novel species, for which the name Mariniflexile fucanivorans sp. nov. is proposed.

\section{Description of Mariniflexile fucanivorans sp. nov.}

Mariniflexile fucanivorans [fu.ca'ni.vo'rans. N.L. n. fucanum fucan (polyfucose); L. part adj. vorans devouring from L. v. vorare to devour; N.L. part. adj. fucanivorans fucandevouring].

Cells are non-flagellated, Gram-negative rods, $0.3-0.5 \mu \mathrm{m}$ in diameter and 3.0-4.0 $\mu \mathrm{m}$ long, occurring singly or in pairs, with rounded ends. Cells are non-motile in the liquid phase but show active gliding motility on solid surfaces. Colonies on ZoBell 2216E agar are circular, shiny, dark yellow and $2.0-3.0 \mathrm{~mm}$ in diameter after incubation for 5 days. Spreading does not occur at the colony margins. Optimal growth temperature is $25^{\circ} \mathrm{C}$; growth occurs between 4 and $32{ }^{\circ} \mathrm{C}$. Optimal $\mathrm{pH}$ for growth is 7.5; growth does not occur at $\mathrm{pH} 5.0$ or 10.0. Optimal $\mathrm{NaCl}$ concentration for growth is $2.5 \%(\mathrm{w} / \mathrm{v})$ and no growth occurs in the absence of $\mathrm{NaCl}$ or at concentrations $>6 \%$ $(\mathrm{w} / \mathrm{v})$. Under optimal growth conditions, the doubling time is around $3.0 \mathrm{~h}$. Catalase, esterase (C4), esterase lipase (C8), lipase (C14), leucine arylamidase, valine arylamidase, cystine arylamidase, alkaline and acid phosphatases, $\beta$-galactosidase, $\alpha$-glucosidase, $\alpha$-fucosidase, trypsin and $\alpha$-chymotrypsin activities are present, but cytochrome
Table 2. Whole-cell fatty acid profiles of strain $S W 5^{\top}$ and $M$. gromovii $\mathrm{KMM} 6038^{\top}$

Data for M. gromovii KMM $6038^{\mathrm{T}}$ were taken from Nedashkovskaya et al. (2006). Values are percentages of total fatty acids. -, Not detected; NR, not reported; tr, trace $(<1 \%)$. Fatty acids that amounted to $<1 \%$ in both strains are not listed, therefore the totals do not reach $100 \%$. The two strains were cultivated under different conditions.

\begin{tabular}{|c|c|c|}
\hline Fatty acid & Strain SW5 ${ }^{\mathrm{T}}$ & $\begin{array}{c}\text { M. gromovii KMM } \\
6038^{\mathrm{T}}\end{array}$ \\
\hline \multicolumn{3}{|l|}{ Straight-chain } \\
\hline $\mathrm{C}_{15: 0}$ & 4.6 & 13.8 \\
\hline $\mathrm{C}_{16: 0}$ & $\operatorname{tr}$ & 1.4 \\
\hline \multicolumn{3}{|l|}{ Branched-chain } \\
\hline iso- $\mathrm{C}_{14: 0}$ & 2.6 & - \\
\hline iso- $\mathrm{C}_{15: 0}$ & 15.3 & 15.0 \\
\hline iso- $\mathrm{C}_{15: 1}$ & 5.4 & 16.9 \\
\hline anteiso- $\mathrm{C}_{15: 0}$ & 6.7 & 5.4 \\
\hline anteiso- $\mathrm{C}_{15: 1}$ & $\operatorname{tr}$ & 1.6 \\
\hline iso- $\mathrm{C}_{16: 0}$ & 1.8 & 1.0 \\
\hline iso- $\mathrm{C}_{16: 1}$ & 3.1 & 1.5 \\
\hline iso- $\mathrm{C}_{17: 1} \omega 9 c$ & 1.0 & NR \\
\hline \multicolumn{3}{|l|}{ Unsaturated } \\
\hline $\mathrm{C}_{15: 1}$ & 8.7 & 3.1 \\
\hline $\mathrm{C}_{17: 1}$ & 4.2 & 1.1 \\
\hline \multicolumn{3}{|l|}{ Hydroxy } \\
\hline $\mathrm{C}_{15: 0} 2-\mathrm{OH}$ & 2.0 & 1.4 \\
\hline $\mathrm{C}_{15: 0} 3-\mathrm{OH}$ & 3.9 & 1.6 \\
\hline iso- $\mathrm{C}_{15: 0} 3-\mathrm{OH}$ & 8.2 & 4.3 \\
\hline $\mathrm{C}_{16: 0} 3-\mathrm{OH}$ & $\operatorname{tr}$ & 1.1 \\
\hline iso- $\mathrm{C}_{16: 0} 3-\mathrm{OH}$ & 10.0 & 2.5 \\
\hline $\mathrm{C}_{17: 02}-\mathrm{OH}$ & 1.9 & - \\
\hline iso- $\mathrm{C}_{17: 0} 3-\mathrm{OH}$ & 6.8 & 8.9 \\
\hline Summed feature $3^{*}$ & 5.5 & 8.4 \\
\hline Unknown $\dagger$ & 2.7 & NR \\
\hline
\end{tabular}

${ }^{*}$ Summed feature 3 contained iso- $\mathrm{C}_{15: 0} 2-\mathrm{OH}$ and/or $\mathrm{C}_{16: 1} \omega 7 c$, which could not be separated by GLC with the MIDI system. $\dagger$ Sum of unknown fatty acids with an ECL (equivalent chain-length) of $11.543,13.565$ and 16.582 .

oxidase, $\alpha$-galactosidase, $\alpha$-mannosidase and $\beta$-glucuronidase activities are absent. Aesculin, DNA, dextrin, glycogen, starch, alginic acid, $l$-carrageenan and sulphated fucan are hydrolysed, but Tweens 40 and 80 , agar, $\kappa$-carrageenan and gelatin are not. D-Glucose, D-galactose, D-fructose, Lfucose, D-mannose, D-lactose, maltose, cellobiose, gentiobiose and glucuronic acid are used as carbon sources, but L-arabinose, L-rhamnose, trehalose, sucrose, raffinose, glycerol, D-mannitol, adonitol, D-arabitol, L-erythritol, inositol, D-sorbitol, $\mathrm{N}$-acetyl-D-glucosamine and $\mathrm{N}$-acetyl$\mathrm{D}$-galactosamine are not. Acid is produced from D-glucose, D-galactose, D-fructose, D-mannose, trehalose, D-xylose, Dribose, L-fucose, maltose, D-lactose, cellobiose, gentiobiose, amygdalin, mannitol, xylitol, starch, glycogen, arbutin and salicin, but not from D- or L-arabinose, L-rhamnose, 
melibiose, melezitose, turanose, D-lyxose, D-tagatose, Dfucose, L-xylose, L-sorbose, sucrose, raffinose, glycerol, erythritol, D-adonitol, dulcitol, inositol, D-sorbitol, D- or Larabitol, methyl $\alpha$-D-glucoside, methyl $\alpha$-D-mannoside, methyl $\beta$-D-xyloside, $N$-acetylglucosamine or inulin (API $50 \mathrm{CH})$. Growth occurs in the presence of $\left(\mu \mathrm{g} \mathrm{ml} \mathrm{ml}^{-1}\right)$ streptomycin (200) and kanamycin (200), but not in presence of penicillin (200), ampicillin (200), rifampicin (10), tetracycline (10) or chloramphenicol (10). Other characteristics are shown in Table 1. The DNA G+C content of the type strain is $34.5 \mathrm{~mol} \%$.

The type strain is $\operatorname{SW}^{\mathrm{T}}\left(=\mathrm{CIP} 109502^{\mathrm{T}}=\mathrm{DSM} 18792^{\mathrm{T}}\right)$, isolated from mud collected from a water-treatment facility recycling the effluent of an alginate-extraction plant at Landerneau, Brittany, France.

\section{Acknowledgements}

This work was performed in the framework of 'Marine Genomics Europe' NoE 7 (EC contract no. GOCE-CT-2004-505403). The authors thank Nolwenn Calvez for technical assistance and Olga I. Nedashkovskaya (Pacific Institute of Bioorganic Chemistry of the FarEastern Branch of the Russian Academy of Sciences, Vladivostok, Russia) for providing the type strain of Mariniflexile gromovii used in this study.

\section{References}

Barbeyron, T., Kean, C. \& Forterre, P. (1984). DNA adenine methylation of GATC sequences appeared recently in the Escherichia coli lineage. J Bacteriol 160, 586-590.

Benson, D. A., Boguski, M. S., Lipman, D. J., Ostell, J., Ouellette, B. F., Rapp, B. A. \& Wheeler, D. L. (1999). GenBank. Nucleic Acids Res 27, 12-17.

Bernardet, J.-F. \& Nakagawa, Y. (2006). An introduction to the family Flavobacteriaceae. In The Prokaryotes: a Handbook on the Biology of Bacteria, 3rd edn, vol. 7, pp. 455-480. Edited by M. Dworkin, S. Falkow, E. Rosenberg, K. H. Schleifer \& E. Stackebrandt. New York: Springer.

Bernardet, J.-F., Segers, P., Vancanneyt, M., Berthe, F., Kersters, K. \& Vandamme, P. (1996). Cutting a Gordian knot: emended classification and description of the genus Flavobacterium, emended description of the family Flavobacteriaceae, and proposal of Flavobacterium hydatis nom. nov. (basonym, Cytophaga aquatilis Strohl and Tait 1978). Int J Syst Bacteriol 46, 128-148.

Bernardet, J. F., Nakagawa, Y. \& Holmes, B. (2002). Proposed minimal standards for describing new taxa of the family Flavobacteriaceae and emended description of the family. Int J Syst Evol Microbiol 52, 1049-1070.

Colin, S., Deniaud, E., Jam, M., Descamps, V., Chevolot, Y., Kervarec, N., Yvin, J.-C., Barbeyron, T., Michel, G. \& Kloareg, B. (2006). Cloning and biochemical characterization of the fucanase FcnA: definition of a novel glycoside hydrolase family specific for sulfated fucans. Glycobiology 16, 1021-1032.

Descamps, V., Colin, S., Lahaye, M., Jam, M., Richard, C., Potin, P., Barbeyron, T., Yvin, J.-C. \& Kloareg, B. (2006). Isolation and culture of a marine bacterium degrading the sulfated fucans from marine brown algae. Mar Biotechnol 8, 27-39.

Doetsch, R. N. (1981). Determinative methods of light microscopy. In Manual of Methods for General Bacteriology, pp. 21-33. Edited by
P. Gerhardt, R. G. E. Murray, R. N. Costilow, E. W. Nester, W. A. Wood, N. R. Krieg \& G. B. Phillips. Washington, DC: American Society for Microbiology.

Felsenstein, J. (1981). Evolutionary trees from DNA sequences: a maximum likelihood approach. J Mol Evol 17, 368-376.

Felsenstein, J. (1985). Confidence limits on phylogenies: an approach using the bootstrap. Evolution 39, 783-791.

Fitch, W. M. (1971). Toward defining the course of evolution: minimum change for a specific tree topology. Syst Zool 20, 406-416.

Galtier, N., Gouy, M. \& Gautier, C. (1996). SEAVIEW and PHYLO_WIN: two graphic tools for sequence alignment and molecular phylogeny. Comput Appl Biosci 12, 543-548.

Hicks, R. E., Amann, R. I. \& Stahl, D. A. (1992). Dual staining of natural bacterioplankton with $4^{\prime}, 6$-diamino-2-phenylindole and fluorescent oligonucleotide probes targeting kingdom-level $16 \mathrm{~S}$ rRNA sequences. Appl Environ Microbiol 58, 2158-2163.

Hugh, R. \& Leifson, E. (1953). The taxonomic significance of fermentative versus oxidative metabolism of carbohydrates by various negative bacteria. J Bacteriol 66, 24-26.

Ivanova, T. L., Turova, T. P. \& Antonov, A. S. (1988). DNA-DNA hybridization studies on some purple non-sulfur bacteria. Syst Appl Microbiol 10, 259-263.

Johnson, J. L. (1984). DNA reassociation and RNA hybridization of bacterial nucleic acids. In Bergey's Manual of Systematic Bacteriology, vol. 1, pp. 8-11. Edited by N. R. Krieg \& J. G. Holt. Baltimore: Williams \& Wilkins.

Jung, S.-Y., Kang, S.-J., Lee, M.-H., Lee, S.-Y., Oh, T.-K. \& Yoon, J.-H. (2005). Gaetbulibacter saemankumensis gen. nov., sp. nov., a novel member of the family Flavobacteriaceae isolated from a tidal flat sediment in Korea. Int J Syst Evol Microbiol 55, 1845-1849.

Kane, M. D., Poulsen, L. K. \& Stahl, D. A. (1993). Monitoring the enrichment and isolation of sulfate-reducing bacteria by using oligonucleotide hybridization probes designed from environmentally derived 16S rRNA sequences. Appl Environ Microbiol 59, 682-686.

Katoh, K., Misawa, K., Kuma, K. \& Miyata, T. (2002). MAFFT: a novel method for rapid multiple sequence alignment based on fast Fourier transform. Nucleic Acids Res 30, 3059-3066.

Katoh, K., Kuma, K., Toh, H. \& Miyata, T. (2005). MAfFT version 5: improvement in accuracy of multiple sequence alignment. Nucleic Acids Res 33, 511-518.

Kimura, M. (1980). A simple method for estimating evolutionary rates of base substitutions through comparative studies of nucleotide sequences. J Mol Evol 16, 111-120.

Kloareg, B. \& Quatrano, R. S. (1988). Structure of the cell walls of marine algae and ecophysiological functions of the matrix polysaccharides. Oceanogr Mar Biol Ann Rev 26, 259-315.

Kristjánsson, J. K., Hjörleifsdóttir, S., Marteinsson, V. T. \& Alfredsson, G. A. (1994). Thermus scotoductus, sp. nov., a pigmentproducing thermophilic bacterium from hot tap water in Iceland and including Thermus sp. X-1. Syst Appl Microbiol 17, 44-50.

Kwon, K. K., Lee, H.-S., Jung, H.-B., Kang, J.-H. \& Kim, S.-J. (2006). Yeosuana aromativorans gen. nov., sp. nov., a mesophilic marine bacterium belonging to the family Flavobacteriaceae, isolated from estuarine sediment of the South Sea, Korea. Int J Syst Evol Microbiol 56, 727-732.

Lee, S. D. (2007). Tamlana crocina gen. nov., sp. nov., a marine bacterium of the family Flavobacteriaceae, isolated from beach sediment in Korea. Int J Syst Evol Microbiol 57, 764-769.

Mabeau, S. \& Kloareg, B. (1987). Isolation and analysis of the cell walls of brown algae: Fucus spiralis, F. ceranoides, F. vesiculosus, F. serratus, Bifurcaria bifurcata and Laminaria digitata. J Exp Bot 38, 1573-1580. 
Mabeau, S., Kloareg, B. \& Joseleau, J.-P. (1990). Fractionation and analysis of fucans from brown algae. Phytochemistry 29, 2441-2445.

Nedashkovskaya, O. I., Kim, S. B., Han, S. K., Rhee, M.-S., Lysenko, A. M., Rohde, M., Zhukova, N. V., Frolova, G. M., Mikhailov, V. V. \& Bae, K. S. (2004). Algibacter lectus gen. nov., sp. nov., a novel member of the family Flavobacteriaceae isolated from green algae. Int J Syst Evol Microbiol 54, 1257-1261.

Nedashkovskaya, O. I., Kim, S. B., Han, S. K., Snauwaert, C., Vancanneyt, M., Swings, J., Kim, K.-O., Lysenko, A. M., Rohde, M. \& other authors (2005). Winogradskyella thalassocola gen. nov., sp. nov., Winogradskyella epiphytica sp. nov. and Winogradskyella eximia sp. nov., marine bacteria of the family Flavobacteriaceae. Int J Syst Evol Microbiol 55, 49-55.

Nedashkovskaya, O. I., Kim, S. B., Kwak, J., Mikhailov, V. V. \& Bae, K. S. (2006). Mariniflexile gromovii gen. nov., sp. nov., a gliding bacterium isolated from the sea urchin Strongylocentrotus intermedius. Int J Syst Evol Microbiol 56, 1635-1638.

Nichols, C. M., Bowman, J. P. \& Guezennec, J. (2005). Olleya marilimosa gen. nov., sp. nov., an exopolysaccharide-producing marine bacterium from the family Flavobacteriaceae, isolated from the Southern Ocean. Int J Syst Evol Microbiol 55, 1557-1561.

Pearson, W. R. \& Lipman, D. J. (1988). Improved tools for biological sequence comparison. Proc Natl Acad Sci U S A 85, 2444-2448.
Reichenbach, H., Kleinig, H. \& Achenbach, H. (1974). The pigments of Flexibacter elegans: novel and chemosystematically useful compounds. Arch Microbiol 101, 131-144.

Saitou, N. \& Nei, M. (1987). The neighbor-joining method: a new method for reconstructing phylogenetic trees. Mol Biol Evol 4, 406-425.

Sasser, M. (1990). Identification of bacteria by gas chromatography of cellular fatty acids, MIDI Technical Note 101. Newark, DE: MIDI Inc.

Smibert, R. M. \& Krieg, N. R. (1981). General characterization. In Manual of Methods for General Bacteriology, pp. 409-443. Edited by P. Gerhardt, R. G. E. Murray; R. N. Costilow, E. W. Nester, W. A. Wood, N. R. Krieg \& G. B. Phillips. Washington, DC: American Society for Microbiology.

Stackebrandt, E. \& Goebel, B. M. (1994). Taxonomic note: a place for DNA-DNA reassociation and $16 \mathrm{~S}$ rRNA sequence analysis in the present species definition in bacteriology. Int J Syst Bacteriol 44, 846-849.

Zablackis, E. \& Perez, J. (1990). A partially pyruvated carrageenan from Hawaiian Grateloupia filicina (Cryptonemiales, Rhodophyta). Bot Mar 33, 273-276.

ZoBell, C. E. (1941). Studies on marine bacteria. I. The cultural requirements of heterotrophic aerobes. J Mar Res 4, 41-75. 